\title{
Immunization of Cattle Against Rabies Using Inactivated Cell Culture Vaccines
}

\author{
By L. Sihvonen, K. Kulonen and E. Neuvonen
}

National Veterinary and Food Research Institute, Department of Production and Vaccines, and Department of Virology, Helsinki, Finland.

\begin{abstract}
Sihvonen, L., K. Kulonen and E. Neuvonen: Immunization of cattle against rabies using inactivated cell culture vaccines. Acta vet. scand. 1994, 35, 371-376. - Twenty-one heads of cattle were vaccinated with Madibovin, 31 with Rabdomun and 127 with Rabisin on 4 different farms. Rabies neutralizing antibody titre $(\geq 0.5 \mathrm{IU} / \mathrm{ml})$ was detected in $80 \%$ of 163 animals tested about 1 month and in $42 \%$ of 133 animals tested about 1 year after primary vaccination. On 3 of the farms 86 animals received booster vaccination about 1 year after primary vaccination. All these animals had antibody titre $(\geq 0.5$ $\mathrm{IU} / \mathrm{ml}$ ) about 1 month after booster and antibody levels were higher than after the primary vaccination. Rabies antibody titres $(\geq 0.5 \mathrm{IU} / \mathrm{ml})$ were detected in $96 \%$ of 50 animals tested 1 year after the booster. No significant differences ( $p>0.05)$ in antibody levels were detected between animals vaccinated with Madibovin or Rabisin (farm C) respectively with Rabisin or Rabdomun (farm D) at any collection time. Responses to rabies vaccines varied considerably between the farms. After primary vaccination of the animals on 2 farms with the same batch of Rabisin, the antibody levels clearly differed $(p<0.0001)$ between the farms.

Our results indicate that booster is always necessary after primary vaccination to ensure that all animals are protected.
\end{abstract}

field conditions; Finland.

\section{Introduction}

Infected wildlife constitutes a significant reservoir of rabies virus for domestic animals and humans alike. An epidemic of sylvatic rabies was detected in south-eastern Finland in 1988-1989, and oral immunization of raccoon dogs and foxes was carried out (Nyberg et al 1992). Vaccination of dogs and cats was strongly recommended throughout the country. Vaccination was also recommended for cattle and horses in the area where sylvatic rabies was detected. Before this period of time, cattle had never been vaccinated against rabies in this country. Cattle are prone to contamination by wild or domestic carnivores and present a risk to man.
The objective of this study was to determine how long rabies antibody titres were maintained in cattle under field conditions after primary and booster vaccinations. The vaccines chosen are widely used inactivated and adjuvated products based on virus produced in cell cultures. In their experiment Soulebot et al. (1985) recorded, that rabies antibody kinetics in cattle was satisfactory for more than 3 years after a single vaccine injection. Some vaccine producers recommend that cattle should be revaccinated every 3 years with their vaccine. A booster injection is recommended by other vaccine producers every year or every 1,2 or 3 years according to local registeration. 


\section{Materials and methods \\ Rabies vaccines}

1. Madibovin is a commercial inactivated and adjuvated (aluminium hydroxide and saponin) vaccine prepared from the Flury low egg passage strain of rabies virus cultivated in chick fibroblast cell cultures. Cattle were vaccinated with Madibovin batch no. 017, purchased from Hoechst, FRG.

2. Rabdomun is a commercial inactivated and adjuvated (aluminium hydroxide) vaccine prepared from the Flury low egg passage strain of rabies virus cultivated in baby hamster kidney cells (BHK 21). Cattle were vaccinated with Rabdomun batch no. 89-04, purchased from Pitman-Moore, Burgwedel, FRG.

3. Rabisin is a commercial inactivated and adjuvated (aluminium hydroxide) vaccine prepared from rabies virus cultivated in a Nil-cell culture (hamster embryo, monolayer culture). Cattle were vaccinated with Rabisin batch nos 60R742, 80Z061, 80T992, 80E111 or 80A072 purchased from Rhone-Merieux, Lyon, France.

Vaccination of cattle and collection of samples Cattle were vaccinated intramuscularly in the scapular muscles (179 animals). The vaccination was performed and blood samples were taken by local veterinary surgeons. Initially, 21 animals were vaccinated with Madibovin, 31 with Rabdomun and 127 with Rabisin. About 1 year after primary vaccination the then remaining 86 animals received booster vaccination. The vaccination and sampling schedule is shown in Table 1. Blood samples were not available for testing from 16 animals on farm $B$ at the 2 first collection times and from 2 animals on farm $C$ at the first collection time. Farms A and B are state agricultural schools. Farms $\mathrm{C}$ and D are private farms. All animals were older than 9 months, mostly be- tween 1 and 6 years of age. The cattle on farm $\mathrm{C}$ were Friesians and on the other farms Ayrshires mostly. None of the animals had been vaccinated against rabies before.

\section{Antibody determination}

The rabies virus neutralizing antibodies were detected with a modification of the RFFITtest (Smith et al. 1973). Briefly, the sera were titrated on a 96-well microtitre plate in 3-fold dilutions after predilution at 1:10. The sera and the Challenge Virus Strain (rabies virus, WHO, Tubingen, Germany) were incubated at $37^{\circ} \mathrm{C}$ for $90 \mathrm{~min}$, after which $\mathrm{BHK}$ cells were added. The cultures were fixed after $24 \mathrm{~h}$ and stained with anti-rabies fluorescent conjugate (Behringwerke, Marburg, Germany). The challenge dose used was the highest dilution of virus giving $40 \%$ infected cells (fluorescent inclusions). Each time the RFFIT was conducted, a WHO reference serum diluted to contain $0.5 \mathrm{IU} / \mathrm{ml}$ of rabies virus neutralizing antibody was used to ensure quality control. The neutralization index was determined as described by Wiktor et al. (1984). Results of $<0.17 \mathrm{IU} / \mathrm{ml}$ were considered negative. The geometric mean titres (GMT) were calculated from $\log _{10}$ transformed data, which were then transformed into international units (IU/ml). Statistical tests were applied on $\log _{10}$ transformed values. Paired T Test was used to compare antibody levels at different collection times. Two-Sample T Test and AOV + Tukey were used to compare antibody levels between groups.

\section{Results}

GMT values and rabies antibody range in international units .(IU/ml) after the primary and booster vaccinations in different groups are listed in Table 1. The distribution of rabies antibody titres in cattle after vaccination are shown in Table 2. 
Table 1. Geometric mean titre (GMT) of rabies antibody in cattle on different farms after primary (day 0 ) and booster vaccination (day 262-378) with Rabisin, Madibovin or Rabdomun.

\begin{tabular}{|c|c|c|c|c|c|}
\hline \multirow{3}{*}{$\begin{array}{l}\text { Farm- } \\
\text { Vaccine }\end{array}$} & \multicolumn{5}{|c|}{ GMT (IU/ml) / Antibody range / sample size(n) } \\
\hline & \multicolumn{3}{|c|}{ After primary vaccination } & \multicolumn{2}{|c|}{ After booster } \\
\hline & Day 0 & Day $28-48$ & Day 262-378 & Day $31-48$ & Day 365-379 \\
\hline $\begin{array}{l}\text { A- } \\
\text { Rabisin }\end{array}$ & $\begin{array}{l}0.01 \\
<0.17-0.34 \\
\mathrm{n}=51\end{array}$ & $\begin{array}{l}0.86^{\mathrm{e}} \\
<0.17-13.5 \\
\mathrm{n}=51\end{array}$ & $\begin{array}{l}0.53^{\mathrm{d}} \\
<0.17-13.5 \\
\mathrm{n}=29\end{array}$ & $\begin{array}{l}8.08^{\mathrm{e}} \\
1.5-13.5 \\
\mathrm{n}=16\end{array}$ & $\begin{array}{l}3.12^{\mathrm{f}} \\
1.5-13.5 \\
\mathrm{n}=6\end{array}$ \\
\hline $\begin{array}{l}\text { B- } \\
\text { Rabisin }\end{array}$ & $\begin{array}{l}0.01 \\
<0.17-0.34 \\
\mathrm{n}=30^{\mathrm{a}}\end{array}$ & $\begin{array}{l}0.07^{\mathrm{d}} \\
<0.17-1.5 \\
\mathrm{n}=30^{\mathrm{a}}\end{array}$ & $\begin{array}{l}0.03^{\mathrm{d}} \\
<0.17-0.5 \\
\mathrm{n}=40\end{array}$ & $\begin{array}{l}2.38^{\mathrm{e}} \\
0.5-40.5 \\
\mathrm{n}=39\end{array}$ & $\begin{array}{l}3.11^{\mathrm{f}} \\
0-40.5 \\
\mathrm{n}=22\end{array}$ \\
\hline $\begin{array}{l}\mathrm{C}- \\
{ }^{8} \text { Rabisin }\end{array}$ & $\begin{array}{l}0 \\
<0.17 \\
n=22\end{array}$ & $\begin{array}{l}2.02^{\mathrm{e}} \\
0.5-13.5 \\
\mathrm{n}=22\end{array}$ & $\begin{array}{l}0.51^{\mathrm{c}} \\
<0.17-13.5 \\
\mathrm{n}=17\end{array}$ & $\begin{array}{l}15.63^{\mathrm{e}} \\
0.5-121.5 \\
\mathrm{n}=15\end{array}$ & $\begin{array}{l}2.09^{d} \\
0.5-4.5 \\
n=10\end{array}$ \\
\hline $\begin{array}{l}\text { C- } \\
\text { sMadibovin }\end{array}$ & $\begin{array}{l}0.01 \\
<0.17-0.17 \\
\mathrm{n}=21\end{array}$ & $\begin{array}{l}1.98^{\mathrm{e}} \\
0.5-13.5 \\
\mathrm{n}=21\end{array}$ & $\begin{array}{l}0.40^{c} \\
<0.17-4.5 \\
n=16\end{array}$ & $\begin{array}{l}16.59^{\mathrm{e}} \\
4.5-121.5 \\
\mathrm{n}=16\end{array}$ & $\begin{array}{l}1.83^{e} \\
0.5-4.5 \\
n=11\end{array}$ \\
\hline $\begin{array}{l}\text { D- } \\
{ }^{n} \text { Rabdomun }\end{array}$ & $\begin{array}{l}0 \\
<0.17 \\
\mathrm{n}=29^{\mathrm{b}}\end{array}$ & $\begin{array}{l}1.45^{\mathrm{e}} \\
0.17-4.5 \\
\mathrm{n}=31\end{array}$ & $\begin{array}{l}0.28^{\mathrm{e}} \\
<0.17-1.5 \\
\mathrm{n}=26\end{array}$ & & \\
\hline $\begin{array}{l}\text { D- } \\
{ }^{\mathrm{n}} \text { Rabisin }\end{array}$ & $\begin{array}{l}0 \\
<0.17 \\
n=8\end{array}$ & $\begin{array}{l}1.14^{\mathrm{e}} \\
0.17-13.5 \\
\mathrm{n}=8\end{array}$ & $\begin{array}{l}0.21^{\mathrm{c}} \\
0.17-0.50 \\
\mathrm{n}=5\end{array}$ & & \\
\hline
\end{tabular}

${ }^{\mathrm{a}} 16$ and $\mathrm{b} 2$ sera were not available for testing.

Significantly different from preceding antibody level: ${ }^{\mathrm{c}} \mathrm{p}<0.05 ;{ }^{\mathrm{d}} \mathrm{p}<0.001 ;{ }^{\mathrm{e}} \mathrm{p}<0.0001$

'No significant difference $(\mathrm{p}>0.05)$ from preceding antibody level

No significant difference $(p>0.05)$ in antibody levels between animals vaccinated with Rabisin or Madibovin ${ }^{8}$ (farm C) respectively with Rabisin or Rabdomun ${ }^{\mathrm{h}}$ (farm D) at any collection time.

Table 2. Rabies antibody titres and geometric mean titres in cattle after vaccination with Rabisin, Madibovin or Rabdomun.

\begin{tabular}{|c|c|c|c|c|c|}
\hline \multirow{2}{*}{$\begin{array}{l}\text { Rabies } \\
\text { antibody } \\
\text { titre IU/ml }\end{array}$} & \multicolumn{3}{|c|}{$\begin{array}{c}\text { Day } \\
\text { after primary vaccination }\end{array}$} & \multicolumn{2}{|c|}{$\begin{array}{c}\text { Day } \\
\text { after booster }\end{array}$} \\
\hline & 0 & $28-48$ & $262-378$ & $31-48$ & $365-379$ \\
\hline$<0.5$ & 161 & 33 & 77 & 0 & 2 \\
\hline 0.5 & 0 & 28 & 26 & 6 & 4 \\
\hline $1-3$ & 0 & 68 & 21 & 24 & 18 \\
\hline $4.5-13.5$ & 0 & 34 & 9 & 45 & 25 \\
\hline $40.5-121.5$ & 0 & 0 & 0 & 11 & 1 \\
\hline Sample size & 161 & 163 & 133 & 86 & 50 \\
\hline GMT IU/ml & 0.01 & $0.76^{a}$ & $0.18^{\mathrm{a}}$ & $5.96^{\mathrm{a}}$ & $2.56^{\mathrm{b}}$ \\
\hline $\begin{array}{l}\text { Antibody } \\
\text { range IU/ml }\end{array}$ & $<0.17-0.34$ & $<0.17-13.5$ & $<0.17-13.5$ & $0.5-121.5$ & $<0.17-40.5$ \\
\hline
\end{tabular}

Significantly different from preceding antibody level: ${ }^{\mathrm{a}} \mathrm{p}<0.0001 ;{ }^{\mathrm{b}} \mathrm{p}=0.0014$. 
Table 3. Geometric mean titre of rabies antibody in cattle on farms A and B after primary and booster vaccination with the same the Rabisin batch.

\begin{tabular}{|c|c|c|c|c|c|}
\hline \multirow[b]{3}{*}{ Farm } & \multicolumn{5}{|c|}{ GMT (IU/ml)/ antibody range / sample size (n) } \\
\hline & \multicolumn{3}{|c|}{ After primary vaccination } & \multicolumn{2}{|c|}{ After booster } \\
\hline & $\overline{\text { Day } 0}$ & Day $28-30$ & Day354-370 & Day 31-48 & Day365-379 \\
\hline A & $\begin{array}{l}0.01 \\
<0.17-0.34 \\
\mathrm{n}=34\end{array}$ & $\begin{array}{l}0.73^{\mathrm{c}} \\
<0.17-13.5 \\
\mathrm{n}=34\end{array}$ & $\begin{array}{l}0.25^{\mathrm{d}} \\
<0.17-3 \\
\mathrm{n}=16\end{array}$ & $\begin{array}{l}8.08^{e} \\
1.5-13.5 \\
n=16\end{array}$ & $\begin{array}{l}3.12^{\mathrm{f}} \\
1.5-13.5 \\
\mathrm{n}=6\end{array}$ \\
\hline B & $\begin{array}{l}0.01 \\
<0.17-0.34 \\
\mathrm{n}=30\end{array}$ & $\begin{array}{l}0.07^{\mathrm{c}} \\
<0.17-1.5 \\
\mathrm{n}=30\end{array}$ & $\begin{array}{l}0.02^{\mathrm{d}} \\
<0.17-0.5 \\
\mathrm{n}=24\end{array}$ & $\begin{array}{l}2.28^{\mathrm{e}} \\
<0.5-40.5 \\
\mathrm{n}=23\end{array}$ & $\begin{array}{l}1.00^{\mathrm{f}} \\
<0.17-4.5 \\
\mathrm{n}=10\end{array}$ \\
\hline
\end{tabular}

Significantly different from corresponding antibody level: $c p<0.0001, d p<0.0001, e p=0.0005$.

No significant difference from corresponding antibody level: $\mathrm{fp}=0.1422$.

About 1 month (28-48 days) after primary vaccination, rabies neutralizing antibody titre $(\geq 0.5 \mathrm{IU} / \mathrm{ml}$ ) was found in 130 of the 163 sera tested (80\%). One year (262-378 days) after primary vaccination, only 56 of 133 animals $(42 \%)$ on all farms had a rabies antibody titre $\geq 0.5 \mathrm{IU} / \mathrm{ml}$. At $31-48$ days after booster vaccination, rabies neutralizing antibody titre was found in all 86 boosted animals (Table 2). One year (365-379) after boosting, 48 of the 50 animals $(96 \%)$ still had a titre of $\geq 0.5 \mathrm{IU} / \mathrm{ml}$.

On farm $\mathrm{C}$ all animals, in both vaccine groups, showed excellent antibody response. No significant difference $(\mathrm{p}>0.05)$ was detected in antibody levels at any collection time between animals vaccinated with Madibovin or Rabisin (Table 1). No difference ( $p>0.05)$ was either detected between animals vaccinated with Rabdomun or Rabisin on farm D (Table 1).

Comparison between the 4 farms were made for antibody levels at different collection times after vaccination (AOV and Tukey, rejection level 0.05). Farm B differed significantly from all other farms at day 28-48 and at day 262-378 after primary vaccination and at day 31-48 after the booster was given. There was no significant difference between the 3 tested farms (A,B,C) at day 365-379 after booster.
Ten of 30 sampled animals on farm B responded with very low antibody levels; the rest of the animals had no detectable antibody titres after the primary vaccination. There was a statistically significant difference in the levels of antibody at day 28-48 and at day 262-378 after the primary vaccination $(\mathrm{p}<0.0001)$ and at day 31-48 after booster $(\mathrm{p}=0.0005)$ between animals vaccinated with the same Rabisin batch on farms A and B (Table 3). No significant difference $(\mathrm{p}=0.1422)$ in antibody levels was detected on farms A and B 1 year after booster.

\section{Discussion}

Postvaccinal immunity to rabies in animals can be assessed either by performing challenge experiments on the animals or by detecting the presence of neutralizing antibodies. Neutralizing antibodies produced in response to vaccination is an important factor in the protection against rabies infection (Turner 1973, Turner 1978). For human pre-exposure immunization, it is recommended that antibody titres equivalent to at least $0.5 \mathrm{IU} / \mathrm{ml}$ be obtained (Anon. 1984). This same titre was also considered to be a relevant for cattle immunization. 
Rabies neutralizing antibody titres $(\geq 0.5$ $\mathrm{IU} / \mathrm{ml}$ ) were detected in $80 \%$ of the animals about 1 month and in $42 \%$ about 1 year after primary vaccin. Responses to rabies vaccine varied considerably among farms.

All animals on farm $\mathrm{C}$, which had been vaccinated with either Rabisin or Madibovin, responded with good antibody titres. Their antibody levels were also quite good 1 year after the primary vaccination. Farm $\mathrm{C}$ is a high quality farm, with healthy cattle and good husbandry. The results for this farm are similiar to those obtained by Soulebot et al. (1985) for cattle vaccinated against rabies.

Animals on farms A (Rabisin) and D (Rabisin and Rabdomun) had moderate antibody responses after the primary vaccination. These results are similar to those obtained after vaccination of reindeer with Rabisin (Sihvonen et al. 1993).

A part of the animals on farms A and B had been vaccinated with the same batch of $\mathrm{Ra}$ bisin, which had been stored and handled in an equal manner until used on the farms. Responses to the vaccine differed however. Antibody levels on farm B were significantly lower than on farm $A$ after primary vaccination and 31-48 days after booster. No significant difference in antibody levels was detected 1 year after the booster. Farm B is a state agricultural school, with a big turnover of animal technicians and students. In addition, the feeding may not have been optimal. Staphylococcal mastitis, mostly subclinical, also occured on the farm. The stress for the animals was considered higher compared with many other farms. Enviromental and genetic factors may partly explain the low vaccine response.

All animals responded with antibody production to booster vaccination. Rabies antibody titres were detected in $96 \%$ of the animals remaining 1 year after the booster. Booster rabies antibody response was good in all ani- mals on the 3 farms tested (A, B and C). Antibody levels were higher and lasted longer than after primary vaccination.

Our results show, that primary vaccination with 1 dose of inactivated rabies vaccine of tissue culture origin induced moderate but short-term serological conversion in $80 \%$ of cattle in the field. Antibody titres did not last for a whole year in most animals. Responses to rabies vaccine may vary considerably between groups of animals in the field. Genetic and enviromental factors, immunosuppression, stress in general and poor storage of vaccine influence the immune response of vaccination. The booster vaccination induced rabies antibody response in all the animals and antibody titres lasted for a year in almost all the animals. Our results indicate that a booster dose of vaccine is always necessary 1 year after the primary vaccination. To guarantee sufficient protection in all animals, the booster could be given 1 month after the primary vaccination. The immunological memory of previous experience with rabies vaccine appears to be good. One booster guaranteed solid immunity, and antibodies were maintained much longer than after primary vaccination.

\section{Acknowledgements}

We thank veterinary surgeons Terttu Katila, Tiina Kotilainen, Laura Kulkas, Ritva Tynkkynen and Seppo Ukkola for vaccinating the cattle and taking blood samples. The work was supported in part by the Ministry of Agriculture and Forestry,the Veterinary and Food Department, Helsinki, Finland.

\section{References}

Anonymous: WHO Expert Committee on Rabies. Seventh Report, WHO Technical Report Series 709, WHO, Geneva, 1984.

Nyberg M, Kulonen K, Neuvonen E, Ek-Kommonen $C$, Nuorgam M and Westerling B: An epidemic of sylvatic rabies in Finland - Descriptive epidemiology and results of oral vaccination. Acta vet. scand. 1992, 33, 43-57.

Sihvonen L, Kulonen K, Soveri $T$ and Nieminen M: 
Rabies antibody titres in vaccinated reindeer. Acta vet. scand. 1993, 34, 199-202.

Smith JS, Yaeger PA and Baer GM: A rapid reproducible test for determing rabies neutralizing antibody. Bull. WHO. 1973, 48, 535-541.

Soulebot JP, Precausta P, Brun A, Blancou JM, Pepin $M$, Chappuis $G$ and Petermann HG: Immunisation of herbivores against rabies using an inactivated cell culture vaccine. In: Kuwert E, Merieux C, Koprowski H, Bögel K (eds): Rabies in the tropics. Springer-Verlag Berlin 1985, pp.274284.

Turner GS: Humoral and cellural immune responses of mice to rabies and smallpox vaccines. Nature New Biol. 1973, 241, 90-92.

Turner GS: Immunoglobulin (IgG) and (IgM) antibody response to rabies vaccine. J. gen. Virol. 1978, 40, 595-604.

Wiktor TJ, MacFarlan RI, Foggin CM and Koprowski $\mathrm{H}$ : Antigenic analysis of rabies and Mokola virus from Zimbabwe using monoclonal antibodies. Dev. Biol. Stand. 1984, 57, 199-211.

\begin{abstract}
Sammanfattning
Immunisering av nötkreatur mot rabies med inaktiverat cellkultur-vaccin.

Tjugoett nötkreatur vaccinerades med Madibovin, 31 med Rabdomun och 127 med Rabisin mot rabies på 4 besättningar. Antikropps-titer $(\geq 0.5 \mathrm{IU} / \mathrm{ml})$ kunde påvisas hos $80 \%$ av 163 testade djur en månad och hos $42 \%$ av 133 testade djur 1 år efter vaccinationen. Boostervaccination utfördes på 86 kvarvarande djur i 3 besättningar 1 år efter primärvaccinationen. Alla djur hade antikropps-titer $(\geq 0.5 \mathrm{IU} / \mathrm{ml})$ en månad efter boostern och titren var högre än efter primärvaccinationen. Antikropps-titer påvisades hos $96 \%$ av 50 testade djur 1 år efter boostern. Inom besättningarna kunde ingen signifikant skillnad i titer ( $p>0.05)$ påvisas mellan djur som vaccinerats med Rabisin eller Madibovin (farm C) respektive med Rabdomun eller Rabisin (farm D). Immunreaktionen varierade mellan besättningarna. Signifikant skillnad i titer $(\mathrm{p}<0.0001)$ kunde påvisas efter primärvaccinationen mellan djuren i 2 besättningar vaccinerade med samma batch Rabisin.

Resultaten visar, att booster alltid är nödvändig efter primär- vaccination, för att alla djur skall bli skyddade.
\end{abstract}

(Received March 7, 1994; accepted August 19, 1994).

Reprints may be requested from: L. Sihvonen, National Veterinary and Food Research Institute, Epidemiology and Biotechnology Unit, Box 368, SF-00231 Helsinki, Finland. 